\title{
O Antropoceno mais que Humano ${ }^{1}$
}

\author{
Anna Lowenhaupt Tsing ${ }^{1}$ \\ ${ }^{1}$ Universidade da Califórnia, Santa Cruz, CA, Estados Unidos da América
}

\section{Resumo}

Este ensaio expõe alguns dos insights sobre o Antropoceno que obtive no projeto Atlas Feral, um trabalho colaborativo que agrega mais de uma centena de cientistas, acadêmicos, artistas e escritores, de origens variadas, que trazem narrativas baseadas em suas experiências mais íntimas com a terra antropogênica. O Atlas Feral conta as aventuras dos colaboradores não humanos do Antropoceno. Nossos sujeitos são seres vivos e não vivos que, ao se emaranharem em projetos imperiais e industriais humanos, estão ajudando, em larga medida, a destruir a habitabilidade da Terra.

Palavras-chave: Antropoceno. Biologia Feral. Paisagem arruinada. Etnografia Multiespécie.

\section{More than Human Anthropocene}

\begin{abstract}
This essay explains some of the insights about the Anthropocene that I gained working on the Feral Atlas project, which gathers more than a hundred scientists, scholars, artists, and writers, from varied backgrounds, to offer experience-based stories of the anthropogenic earth as they best know it. The Feral Atlas tells the adventures of the nonhuman collaborators with the Anthropocene. Our subjects are living and nonliving beings that-through their entanglement in human imperial and industrial projects-are (in the main) helping to destroy the earth's livability.
\end{abstract}

Keywords: Anthropocene. Feral Biologies. Paisagem Arruinada. Multispecie Anthropocene.

\footnotetext{
Manuscrito da Conferência de Encerramento da VII REACT - Reunião de Antropologia das Ciências e da Tecnologia. Tradução e Revisão Técnica por Leticia Cesarino e Thiago Cardoso.
} 


\section{Introdução}

$\mathrm{N}^{2}$

esta época de terrores ambientais, é difícil não nos perguntarmos sobre as consequências das ações humanas, especialmente por parte dos programas imperiais e industriais que tanto modificaram a terra, a água e a atmosfera do planeta. Como um antropólogo poderia responder a esses terrores? Este ensaio defende a importância de uma descrição melhor do Antropoceno, em todos os seus fragmentos e manchas - uma tarefa que precisa de todo tipo de participantes, desde anciãos indígenas até artistas, cientistas sociais e cientistas naturais, tanto do Norte quanto do Sul global.

Antropólogos têm tido receio de narrar perigos ambientais. Gostaríamos de confirmar a importância da criatividade humana, especialmente daqueles que nunca tiveram reconhecimento por suas habilidades. Gostaríamos, também, de evitar estórias paralisantes, assustadoras a ponto de os leitores perderem a vontade de agir e de intervir. Essas metas são importantes, mas elas devem lançar um desafio, e não fazer com que os acadêmicos se retraiam diante de más notícias. Como podemos contar estórias sobre dilemas de relevância local e contá-las de modo tão atraente que os leitores desejem aprender mais, ainda que aprendam sobre terrores? É esse desafio que eu e meus colegas Jennifer Deger, Feifei Zhou, Alder Keleman Saxena aceitamos na curadoria do projeto digital Atlas Feral: o Antropoceno Mais-que-Humano. O projeto será publicado pela Stanford University Press, em 2020, no site de acesso aberto feralatlas.org.

Este ensaio expõe alguns dos insights sobre o Antropoceno que obtive trabalhando nesse projeto. Ele agrega mais de uma centena de cientistas, acadêmicos, artistas e escritores, de origens variadas, que trazem narrativas baseadas em suas experiências mais íntimas com a terra antropogênica. Nosso projeto conta as aventuras dos colaboradores não humanos do Antropoceno. Ao ler o termo "colaborador", pense em criminosos de guerra, e não em colegas prestativos. Nossos sujeitos são seres vivos e não vivos que, ao se emaranharem em projetos imperiais e industriais humanos, estão ajudando, em larga medida, a destruir a habitabilidade da Terra (também incluímos alguns colaboradores prestativos, benignos e ambíguos.) Nós os chamamos "ferais" para indicar que são suas relações com as infraestruturas imperiais e industriais, e não sua natureza intrínseca, que provocam tantos problemas. Em inglês, o termo "feral" (feral) se refere a animais que escaparam da domesticação. Ampliamos o termo para destacar como seres vivos e não vivos podem ganhar novos poderes ao se associarem aos projetos humanos modificadores da terra, da água e da atmosfera que chamamos de infraestruturas. O Atlas Feral que compilamos aparece em um formato digital que combina características de arquivo, jogo, coletânea e uma reflexão sobre como viver junto, uns com os outros. 
No processo de trabalho com os muitos relatos de campo oferecidos por nossos contribuidores, desenvolvemos uma abordagem para aprender mais sobre o Antropoceno mais-que-humano. O presente ensaio traz os pontos básicos desta abordagem na esperança de que possa auxiliar e inspirar outros. Essas abordagens são teorias em ação, ou seja, teorias que trabalham com materiais empíricos. O que segue é uma série de enquadres a partir dos quais problemas concretos relativos ao Antropoceno podem ser abordados. No processo, introduzo e referencio vários dos ensaios e dos relatos que compõem o Atlas Feral.

\section{Tratar o Antropoceno como Manchas ou Fragmentos}

Boa parte das discussões sobre o Antropoceno começam e terminam com modelagem planetária. O Atlas Feral argumenta que isso não é suficiente: o Antropoceno é patchy (TSING; MATHEWS; BUBANDT, 2019), e precisamos estudar suas manchas (patches) e seus corredores. Na ecologia de paisagem, uma "mancha" é uma composição diferenciada de espécies e condições ecológicas; é parte de uma "paisagem" heterogênea. O Antropoceno oferece algumas manchas ecológicas diferenciadas, como grandes plantações, subúrbios, complexos industriais, instalações logísticas e muito mais. Atentar para as consequências ambientais específicas de cada mancha abre a discussão sobre justiça ambiental em geografias planetárias desiguais.

Para descrever um Antropoceno fragmentado, precisamos de descrições e de pesquisas de campo tanto quanto de modelagens planetárias. Uma abordagem de campo envolve mais do que acrescentar dados a um conjunto de compreensões já estabelecidas. Os antropólogos, por exemplo, podem fazer mais do que estudar reações particulares das pessoas às mudanças climáticas, como se nós já soubéssemos o que as mudanças climáticas são para as ciências naturais. Uma antropologia mais-que-humana pode, pelo contrário, refazer as mudanças climáticas, assim como outros fenômenos do Antropoceno, como objetos de pesquisa. Não se trata de arrogância disciplinar. Precisamos de uma descrição melhor do Antropoceno, e é assim que podemos chegar lá.

Uma melhor descrição começa com experiência e pesquisa baseada em campo. Cientistas de campo naturais e sociais sabem algo sobre a relação entre lugares e as matrizes nas quais eles estão imbricados, e isso abre espaço para a importância de desigualdades regionais. Estudos sobre o Antropoceno devem considerar justiça social. Inversamente, preocupações ambientais devem ser reincorporadas em análises de justiça social. Para a saúde pública, direitos indígenas, justiça alimentar e a mera sobrevivência, mobilizações humanas precisam dar mais, e não menos, atenção aos não humanos.

Consideremos as mudanças climáticas provocadas pelo dióxido de carbono antropogênico, a primeira coisa que vem à mente de muitos quando pensam no Antropoceno - e um problema que muitos de nós veem de forma pouco reflexiva como planetariamente homogêneo. Mas o ciclo de carbono nos mostra manchas e efeitos de massa. Indústrias que queimam combustíveis fósseis produzem manchas densas de dióxido de carbono, que se espalham pela atmosfera. As florestas capturam parte desse dióxido de carbono na respiração vegetal. Essas são manchas de carbono, assim como as profundidades variadas do oceano. Uma descrição fiel da produção e circulação do dióxido 
de carbono requer atenção às estruturas e infraestruturas da paisagem industrial que se difundem e sequestram carbono. Onde estão as indústrias e onde estão as florestas? Desigualdades entre vítimas humanas e não humanas dos efeitos do dióxido de carbono, como o aquecimento global, só podem ser apreendidas investigando infraestruturas e suas consequências.

No Atlas Feral, a artista Anne-Sophie Milon e o geólogo Jan Zalasiewicz (2020) tornam o dióxido de carbono o mais palpável possível. Zalasiewicz apresenta o dióxido de carbono feral como uma massa viajante, um coágulo produzido em lugares particulares que se move por meio do ar e da água com um tempo de vida específico até que ele se dispersa. Ele também aponta para a particularidade de suas vítimas, seja em recifes de corais tropicais ou em florestas boreais. Ao trazer o dióxido de carbono para o campo, os autores materializam a sua produção, deslocamento e efeitos. Isso pode nos mover pelas manchas do Antropoceno.

\section{Observe a Infraestrutura}

O que torna os fragmentos ricos em dióxido de carbono são as infraestruturas industriais que queimam combustíveis fósseis. A atenção a essas infraestruturas diz muito sobre as manchas do Antropoceno. Uso o termo infraestrutura para me referir a projetos que alteram a terra, a água e a atmosfera, pois variam desde as plantations, a fábricas e transações internacionais. Não quero dizer "redes para mudar as coisas", um dos significados comum do termo em antropologia, mas sim algo mais próximo de "obras públicas", isto é, elementos materiais de projetos de governança - embora o termo "obras públicas" tenha saído de moda, e seja cada vez mais difícil encontrar a sua parte "pública". Pense, por favor, em "projeto material de transformação da paisagem", e não em "redes". Nesse sentido, as infraestruturas imperiais e industriais criam manchas sem precedentes de efeitos ferais. Feral não é necessariamente negativo: precisamos de florestas ferais crescendo em fazendas abandonadas, apenas para dar um exemplo. O Holoceno é repleto de efeitos ferais. Ainda assim, a discussão sobre o antropoceno orienta nossa atenção para perigosas feralidades. Os efeitos ferozes das infraestruturas imperiais e industriais são o Antropoceno, em todos os seus terrores.

Considere o relatório do Feral Atlas, de Marissa Weiss (2020), uma cientista florestal, de Harvard. Weiss (2020) escreve para a Feral Atlas sobre insetos que viajam com paletes de transporte de madeira, como broca cinza-esmeralda, que está matando milhões de árvores de freixos americanos. Weiss (2020) explica: “Infestações devastadoras por besouros perfurantes, rastreáveis em paletes de madeira, ameaçam refazer as florestas dos EUA em um ritmo sem precedentes e com consequências ainda desconhecidas". Ela explica também a infraestrutura:

O palete de madeira maciça para exportação é tão onipresente que se tornou quase invisível, mas estão no coração do setor de exportação global que definiu a economia moderna. Somente nos Estados Unidos, agora existem cerca de 2 bilhões de paletes em circulação e cerca de $94 \%$ de todos os produtos dos EUA já estiveram no topo de suas ripas. (WEISS, 2020) 
Weiss (2020) conta a história do desenvolvimento de paletes de transporte de madeira como uma tecnologia militar americana durante a Segunda Guerra Mundial e da sua propagação posterior no centro do transporte comercial. Ela escreve:

Os paletes tornaram-se indispensáveis porque facilitavam transferências rápidas de mercadorias de navios para trens e caminhões. [...] [P] aletes estavam no centro do boom americano de consumo no pós-guerra e continuaram a desempenhar um papel central no crescimento exponencial do comércio internacional nos últimos 70 anos. (WEISS, 2020)

Uso aqui um exemplo de infraestrutura que possui um recurso de rede, mas observe que meu argumento sobre infraestrutura tem a ver com a sua manifestação material. Weiss (2020) escreve:

Os problemas dos paletes para as florestas começam com os ecossistemas da própria madeira, especificamente quem ou o que está vivendo na madeirafonte. "Os paletes movem o mundo", diz Mark White, professor emérito da Virginia Tech e diretor do Laboratório de Pesquisa de Paletes e Recipientes William H. Sardo Jr. e do Centro de Design de Embalagens e Cargas Unitárias. E o mundo inclui mais do que apenas bens de consumo. Os paletes também transportam insetos vivos e doenças de plantas que fazem parte do ecossistema doméstico, expondo as árvores no seu destino a novas ameaças.

Esse problema, ela argumenta, se intensificou no final do século XX, quando as empresas americanas mudaram as fábricas para o exterior, e a maioria dos bens usados nos EUA passou a viajar a partir de portos distantes em paletes de florestas amplamente distribuídas. A enorme escala da introdução de insetos garante que alguns deles encontrem um ponto de apoio nas florestas americanas, pois eles continuarão matando as árvores, assim como as plantas e animais que as árvores sustentam.

Weiss (2020) explica muito bem um dos meus argumentos principais: os criadores não humanos do Antropoceno são entidades que tiram proveito das possibilidades das infraestruturas humanas. Os insetos usam paletes para encontrar novas casas. No processo, eles mudam completamente as florestas, às vezes acabando com elas. Esse é o Antropoceno mais-que-humano dos efeitos ferais. Aqui, os insetos são nossas entidades ferais, nossos coconspiradores do Antropoceno. Os paletes de remessa são a infraestrutura que os refaz como matadores de florestas. O estudo do Antropoceno deve começar com as infraestruturas e os seres refeitos por essas infraestruturas - como brocas cinzaesmeralda que destroem as florestas americanas.

\section{Considerar como Infraestruturas que Emergem Dentro de Programas de Invasão, Império, Capital e de Aceleração}

Como o exemplo dos paletes mostra, infraestruturas não são apenas pedaços aleatórios de mágica tecnológica. Elas se desenvolvem na violência de economias políticas e programas culturais. No Atlas Feral, enfatizamos a importância de quatro programas de desenvolvimento infraestrutural: invasão, império, capital e aceleração. Chamamos estes de "detonadores do Antropoceno", porque eles ativam formas do Antropoceno por meio de novos tipos de desenvolvimento infraestrutural. Esses detonadores são ativados 
por eventos históricos, mas não periodizam a história. E não se trata de uma cronologia: todos esses quatro estão conosco no presente. Embora nosso programa de "invasão" tenha começado com a invasão europeia nas Américas há 500 anos, ela continua hoje em todas as formas de colônias de povoamento. Consideramos introduções biológicas impensadas, como a da "lesma canibal" no Havaí, que está devorando os caramujos nativos até a extinção (HADFIELD, 2020), como parte desse tipo de colonialismo na contemporaneidade. Da mesma forma, o governo por elites a longas distâncias, capitaneado pelo colonialismo europeu, persiste em boa parte das principais infraestruturas contemporâneas. Paletes de transporte, descritos por Weiss como uma aplicação militar, contêm neles império. Mas paletes também são criaturas do capital, o programa que transforma trabalho humano e não humano em recursos para investidores distantes. Aceleração, pela qual entendemos a Grande Aceleração após a Segunda Guerra Mundial, difunde e democratiza programas imperiais e industriais, para que todos os povos possam ter a sua chance de destruir a terra.

A aceleração também conta com suas próprias feralidades infraestruturais, envolvendo especialmente gestão de rejeitos (ou sua ausência) de longa vida como plásticos e radioatividade. Em seu livro Plutopia, a historiadora Kate Brown (2013) mostrou como arranjos sociais americanos de raça e gênero ajudaram a construir tanto a segurança imaginada quanto o descarte negligente de rejeitos da Grande Aceleração global. No Atlas Feral, ela continua a mapear nosso tempo mostrando como Chernobyl se tornou global - por meio da coleta de mirtilos (BROWN, 2020). Eis um excerto:

Os catadores de mirtilo se deslocam em bicicletas ou se apinham em vans de carga. São jovens, em sua maioria mulheres e crianças, magros, queimados de sol, com as mãos tingidas de um roxo profundo. Desde o acidente nuclear de Chernobyl em 1986, comunidades rurais do norte da Ucrânia e sul da Bielorússia tentam ganhar a vida. Surpreendentemente, nos últimos anos cidades da Região de Polesia no norte da Ucrânia cresceram rápido. O que está mudando a economia local? A coleta em massa de cogumelos e mirtilos selvagens orgânicos nas florestas pantanosas. Essa nova economia local enriquece a dieta global com Césio radioativo do acidente de Chernobyl.

Os catadores se baseiam em seu conhecimento ancestral da floresta para encontrar as frutas. Neste território de solos minerais pobres, a agricultura de trigo e arado nunca vicejou. Os polesianos então substituíram-na por produtos florestais: caça, peixe, frutas, ervas e fungos. O que mudou em anos recentes foi a escala industrial da coleta de frutas. Centenas de compradores ocupam a beira das estradas, cada um comprando uma ou duas toneladas diárias de frutas na alta estação. A exportação da Ucrânia para a Europa de frutas poleisanas orgânicas aumentou mais de trinta vezes desde 2014. Após a temporada de mirtilos, os catadores voltam às florestas em agosto para colher cranberries, e na estação chuvosa, cogumelos.

Os compradores vendem a compra do dia para um atacadista de um grande armazém. Ali, um monitor de radiação passa sobre as frutinhas roxas

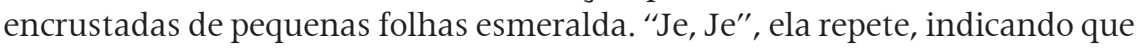
a contagem de energia radioativa dos mirtilos ultrapassa o nível permitido. Metade das frutas que estavam nos sacos continham dose além da permitida. $\mathrm{O}$ atacadista compra todas, inclusive as inadequadas com desconto. Misturando mirtilos com altas contagens com os mais limpos, eles conseguem ficar abaixo do limiar americano e europeu de 1250 becquerels por quilo. 
Muito antes do quarto reator de Chernobyl explodir, os cientistas sabiam que os pântanos polesianos, com seu denso emaranhado de brejos, riachos, lagos e lamaçais, eram bons re-circuladores de isótopos radionativos, canalizandoos para plantas sedentas por minerais, que avidamente bebem os isótopos que emulam os minerais necessários à sua sobrevivência. Frutas e cogumelos são produtos florestais clássicos, porque eles retiram o que podem do solo pobre das florestas. Os poleisanos, também habitantes clássicos da floresta, aprenderam a fazer o mesmo.

Muitas agências internacionais tentaram desenvolver programas para revitalizar as economias afetadas pelo acidente. Todas falharam. Ninguém nunca recomendou reviver a economia local através da colheita do produto mais radioativo de Chernobyl, mas poucos consultaram os polesianos sobre como proceder após o desastre nuclear. Abandonados à própria sorte de lidar com o maior desastre tecnogênico do mundo, os polesianos aprenderam a se virar com o que tinham. (BROWN, 2020)

Aqui, a entidade feral é a própria radioatividade. Saída de uma usina nuclear (nossa infraestrutura), a radioatividade toma seu próprio rumo, penetrando o metabolismo de plantas, fungos e animais. O Antropoceno é, novamente, um efeito feral, um efeito da ação mais-que-humana. Brown conclui com uma estória sobre mirtilos de Chernobyl no mercado de mirtilos da América do Norte. Um caminhão foi parado na fronteira CanadáEUA porque carregava uma grande massa radioativa. Eram os mirtilos de Chernobyl - e a patrulha da fronteira deixou passar, visto que não há é ilegal vender mirtilos radioativos. Chequei na minha geladeira e vi um pacote de mirtilos selvagens orgânicos que dizia "embalado em Maine". Hmmm...

\section{As Infraestruturas nos Mostram a Estrutura da Paisagem}

As infraestruturas nos mostram as formas pelas quais manchas antropocênicas são criadas, isto é, a estrutura da paisagem. Considere as plantações de café na Costa Rica. Ao matar todas as outras plantas e permitir apenas café, os proprietários criaram uma monocultura de plantation, que, segundo a agroecologista Ivette Perfecto (2020), incentiva pragas e doenças de plantas como o fungo ferrugem do café. Essa não é a única maneira de cultivar café. Os pequenos agricultores da América Central plantam café à sombra e em conjunto com uma variedade de outras plantas. Infelizmente, uma vez que as plantações tenham atraído organismos doentes, causando uma epidemia, a doença se espalha além da plantação, para pomares e fazendas de pequenos agricultores. Para entender a situação, é preciso começar com o que estou chamando de "estrutura da paisagem", ou seja, padrões iteráveis de distúrbios humanos: aqui, a monocultura de café. A plantation é uma estrutura que dá especificidade a essa mancha. O problema da difusão de doenças de plantas no Antropoceno só pode ser estudado em relação a essa estrutura da paisagem.

As infraestruturas imperiais e industriais fazem os tipos de trabalho que os humanos sempre fizeram - mas com uma diferença. Há uma brecha, uma traição, entre as maneiras humanas comuns de fazer as coisas e os grandes projetos de invasão, império, capital e aceleração da construção de infraestrutura. No Atlas Feral, tentamos chegar a essa 
fenda através de um conceito que chamamos de "basculantes" ou "mudanças de estado mediadas por infraestrutura". Elas descrevem uma mudança no registro, uma ruptura com a prática vernacular oferecida pelas infraestruturas imperiais e industriais. O termo “basculante" pretende invocar pontos de inflexão. No caso do café da América Central, a plantation ordena e simplifica a produção. Chamamos essa mudança de estado mediada pela infraestrutura de "grade".

Organizar as culturas também é o que você faz quando planta vegetais em seu jardim. Mas algo está diferente. A herança da monocultura do café a céu aberto na América Latina é a plantation do Novo Mundo, patrocinada pela Europa, na qual as ecologias foram simplificadas para fazer uso do trabalho humano coagido, trabalho conquistado pela escravidão. A simplificação das culturas foi construída para um sistema de alienação no qual não se esperava que os trabalhadores prestassem atenção a uma multiplicidade de ritmos de plantas. A plantation empacotou a alienação humana com alienação ecológica, na qual as plantas foram separadas das espécies associadas para uma reprodução forçada uniforme. É nesse legado que o cultivo de café em pleno sol, como uma monocultura, abre o café para o fungo da ferrugem-do-café. Todas as plantation são assim; de fato, é tentador pensar na alienação ecológica como um estado que atrai patógenos. A simplificação da ecologia que entra em uma plantation reúne e alimenta doenças, e até cria doenças novas. Essa é a traição da "grade". Por meio de mudanças de estado mediadas por infraestrutura, neste caso a grade, o Atlas Feral coloca a traição da plantação de café em diálogo com outras formas de violência infraestrutural.

John Bellamy Foster (1999) propôs o termo "fenda metabólica" para descrever a visão de Marx de que a agricultura capitalista esgota o solo movendo nutrientes do campo para a cidade. Esta é uma maneira de descrever as traições que emergem das infraestruturas industriais. Cada um dos complexos de infraestrutura que descrevemos no Atlas Feral oferece suas próprias formas de ruptura metabólica. A plantação trai a pequena fazenda alimentando doenças. O comércio global através de paletes de transação trai as trocas diárias inundando florestas com pragas potencialmente invasivas. Em cada caso, as infraestruturas nos levam a estruturas paisagísticas que mostram como essas fendas metabólicas são realizadas. A plantation é um bom exemplo, porque sua diferença morfológica com relação a uma fazenda camponesa deixa bem clara a estrutura paisagística da traição - a monocultura ecologicamente perigosa.

Os cientistas sociais passaram o último meio século se preocupando com saber se a estrutura ou a agência é mais importante. Ultimamente, estamos no modo de agência e, quando falo com colegas sobre a estrutura da paisagem, eles costumam dizer "Onde estão as pessoas?" Como meu colega Nils Bubandt apontou, quando os antropólogos perguntam isso, geralmente querem dizer a fenomenologia da experiência humana individual. Eles querem a intimidade emocional de um encontro com outro ser humano, e não a veem em um diagrama da estrutura da paisagem. Mas considere onde isso nos leva. Houve uma grande, e na minha opinião equivocada, discussão sobre quem é o responsável pelo Antropoceno. Todos os seres humanos são responsáveis? Ou são apenas empresários gananciosos? São pessoas más ou todas as pessoas? E se alguém tem bom coração, pode ser responsabilizado se ajudar a produzir efeitos negativos? Não pretendíamos destruir tudo. Essa conversa está fazendo as perguntas erradas. 
O Antropoceno não é uma questão de bondade ou ganância. Isso nos faz, tanto quanto nós o fazemos. Estamos ligados ao Antropoceno pelas infraestruturas que compõem as estruturas da paisagem. Se quisermos trabalhar com intimidades emocionais, é melhor perguntarmos sobre investimentos pessoais nessas estruturas da paisagem. Uma de minhas colegas, Rachel Cypher (2020), está perguntando como um amor aterrador liga os fazendeiros às plantações de soja na Argentina. O amor envolve as pessoas com a terra e seus lucros. O amor naturaliza pesticidas. Mas isso não é amor de pessoa para pessoa; esse é o amor que reproduz e amplia a estrutura da paisagem.

\section{A Escala Adequada Depende do Processo Feral}

Qual o tamanho da mancha de paisagem que um pesquisador deve estudar? Isso depende totalmente do fenômeno em questão. Se você estuda o fungo da ferrugem-docafé, você deve seguir a ferrugem onde quer que ela vá. Não é possível escolher a escala de antemão. Ao invés de estabelecer os termos, a escala emerge a partir dos problemas associados com a estrutura da paisagem. Lembram dos insetos viajando nos paletes de madeira? As manchas que emergem a partir da relação entre insetos e paletes que viajam são os corredores da logística global. Note como essas rotas privilegiam certas cidades portuárias. Pragas de insetos invasivos frequentemente encontram acolhida em cidades portuárias, e viajam mais lentamente a partir desses pontos. Aqui, a estrutura da paisagem diferencia entre os portos e os lugares no interior. E os mirtilos radioativos de Chernobyl? A pluma de rádio-césio de Chernobyl foi varrida junto com os ventos para a Europa e Ásia. Essa pluma oferece um nível de estrutura de paisagem: plantas, animais e fungos dentro dessa pluma provavelmente coletam radioatividade. Mas isso não é suficiente para estudar mirtilos radioativos. Também precisamos da estrutura do comércio global de mirtilos, que transporta a radioatividade para novos locais.

Talvez pareça confuso ter que fazer uma nova escala para cada problema. Mas uma vez que se pega o jeito de como o observar a infraestrutura, não é difícil. Se a infraestrutura tem a ver com monoculturas, a estrutura de mancha que você busca segue as plantações. Se tem a ver com a distribuição da radioatividade, a estrutura de paisagem que você precisa segue a radioatividade. O Atlas Feral encoraja os pesquisadores a tentarem esse procedimento para diversos tipos de projeto. Quais infraestruturas estão envolvidas? Quais manchas de estruturas de paisagem elas produzem? Como as formas de coerção e disciplina de humanos e não humanos estão interligadas? Quais suas consequências ferais? Encorajamos jovens - e velhos - acadêmicos a perceber como isso abre questões de pesquisa no que era uma zona de isolamento entre as ciências naturais e as humanidades.

Antes de deixar a estrutura da paisagem, permitam-se contar sobre outro verbete do Atlas Feral: vacas comedoras de plástico em Karnataka (NAGY, 2020). A mancha aqui é o terreno urbano em que vacas leiteiras buscam alimento diariamente, e onde repousam quando estão cansadas. Karnataka é uma cidade majoritariamente hindu, e as pessoas amam as vacas e seu leite. As vacas não são ferais: elas pertencem ao povo da cidade, que vende o leite no mercado local de laticínios. O que é feral é o plástico: jogado nas ruas, normalmente contendo restos de comida, disponíveis para qualquer um que 
deseje experimentar. O geógrafo Kelsi Nagy descobriu que, quando podem escolher, as vacas de Karnataka preferem comer restos de comida - normalmente embrulhados em plástico - a grama fresca. Há mais calorias e gosto doce no lixão. Mas o plástico penetra em seus corpos, e no seu leite. Os moradores de Karnataka preferem o leite local, por considerá-lo mais saudável. Mas resíduos de plástico dissolvido entram no leite. É a ação feral do Antropoceno. E é a estrutura de paisagem produzida pelo resíduo plástico que nos oferece a melhor pista para esta situação.

\section{Cotemporalidades são Importantes}

Minha próxima abordagem é sobre a cotemporalidade, isso significa apenas que muitas coisas estão acontecendo ao mesmo tempo. Isso deveria ser óbvio. A única razão pela qual não é, é que todos nós fomos treinados em uma ideologia modernista específica que chamamos de "progresso". Nas narrativas de progresso, apenas uma trajetória importa: a que nos leva à frente, ao futuro. Tudo o que acontece ao nosso redor é irrelevante. Aprendemos a parar de prestar atenção em tudo, exceto naquela trajetória privilegiada que identificamos com o progresso. Ação não humana, pessoas não ocidentais: elas não faziam parte do progresso. Eles foram o pano de fundo para a ação histórica das elites ocidentais. Era uma espécie de cegueira, e o Antropoceno é um lembrete de que isso não serve mais. Precisamos prestar atenção às temporalidades de muitos tipos de seres; eles estão fazendo história, assim como nós.

Pode ser útil relembrar um momento anterior em que cientistas sociais levantaram questões de cotemporalidade, mas envolvendo exclusivamente seres humanos. Johannes Fabian escreveu um livro influente chamado O Tempo e o Outro, publicado em 1983. Fabian argumentou que, enquanto trabalhavam em campo, os etnógrafos compartilhavam um senso comum de tempo com as pessoas nas comunidades que estudavam, mas, ao escrever suas etnografias, os antropólogos colocavam essas comunidades em uma atemporalidade que negava suas histórias comuns aos escritores. Mesmo onde os antropólogos não estereotiparam as pessoas que estudaram como "primitivas", eles criaram esse espaço selvagem, mais uma vez, usando um presente etnográfico que negava o tempo às comunidades estudadas. Essas comunidades estavam fora da história, em alguma outra prateleira do tempo. Os antropólogos se consideravam parte da história moderna, isto é, do progresso, mas as pessoas que estudamos estavam em algum limbo temporal, fora do progresso. Isso não faz sentido, argumentou Fabian. Os antropólogos precisavam, refletiu ele, trazer as pessoas com quem trabalhamos de volta ao tempo comum no qual os encontros antropológicos do trabalho de campo são possíveis.

Vamos estender esse importante insight para os não humanos. Desenvolvemos hábitos de considerar outros seres como estáticos, presos no mesmo espaço atemporal que o primitivo. Imaginamos que eles também estão fora do progresso e, portanto, sem tempo e história. Pensamos em outras espécies como tendo evoluído há muito tempo milhões de anos ou mesmo centenas de milhões de anos atrás. Depois disso, fingimos que eles permanecem iguais, repetindo suas rotinas. Assim como as pessoas primitivas, imaginadas pelos ocidentais confusos com o progresso. De fato, os não humanos estão 
fazendo história ao lado dos humanos. Em muitos casos, mudamos juntos, humanos e não humanos, na mesma escala de tempo. Às vezes, sua historicidade muda tudo. Precisamos começar a prestar atenção.

A antropóloga Paulla Ebron (2020) examinou novamente o tráfico de escravos do Atlântico em seu verbete no Atlas Feral. Navios negreiros lotavam e confinavam corpos africanos acima e abaixo do convés. Essa organização de corpos imobilizados é uma espécie de estrutura paisagística. "O que mais estava vivendo no navio negreiro?", perguntou Ebron. E os vermes: ratos, piolhos e mosquitos - para não falar de vírus e bactérias? Uma vez que começamos a pensar em cotemporalidades, todas as criaturas que convivem com corpos humanos - especialmente corpos acorrentados na imundície - tornam-se importantes para fazer a experiência histórica das pessoas escravizadas. Navios negreiros carregavam mais que corpos humanos. E a experiência de ser transportada através do Atlântico - tão importante para as histórias humanas - foi igualmente importante para as histórias não humanas. De fato, argumenta Ebron, é impossível entender a desumanização dos africanos escravizados sem uma maior atenção às suas relações sociais mais-que-humanas.

Um companheiro de viagem se destaca: o mosquito Aedes aegyptii, que formou uma população nova e particularmente mortal nessas viagens atlânticas. No Velho Mundo, havia várias populações distintas de Aedes aegyptii, que antes do comércio no Atlântico não eram encontradas nas Américas. Uma população, no Mediterrâneo e no Norte da África, aprendeu a viver em estreita colaboração com os seres humanos, se recriando em recipientes de água humana e vivendo em casas. Alguns cientistas chamam isso de "domesticação" (POWERLL; TABACHNICK, 2013), mas, nesse caso, é domesticação para os fins dos mosquitos. Muitos marinheiros do comércio transatlântico eram do Mediterrâneo, e talvez os navios capturassem essa população lá. Porém, ao carregar pessoas escravizadas nos portos da África Ocidental, uma população diferente do Aedes aegyptii foi encontrada, e esta carregava o vírus da febre amarela. Nesse encontro, no ambiente dos navios, emergiu uma nova e distinta população de Aedes aegyptii. Ele tinha o hábito de viver perto de humanos, além de uma capacidade aprimorada de transmitir febre amarela. Era algo original: todos os mosquitos Aedes aegyptii no Novo Mundo são descendentes dessa população imigrante. Não é africano nem mediterrâneo, mas algo que emergiu dos navios. E provou ser muito mortal. As plantações para as quais os africanos escravizados foram trazidos eram ótimos lugares para o novo mosquito, com recipientes de água para procriação e muita gente para refeições de sangue. A febre amarela enlouqueceu, mudando o curso da história. O historiador John McNeil (2010) argumentou que os impérios ficaram e partiram por causa do mosquito. Ebron (no prelo) mostra a importância do mosquito para a região sudeste dos EUA, conhecida por uma cultura Gullah africana. Como os plantadores brancos tinham medo de se estabelecer ali, devido às febres, os africanos tinham mais autonomia que em outros lugares da América do Norte, e a cultura Gullah se desenvolveu a partir dessa autonomia. Esse mosquito fez história como parte de sua cotemporalidade com os seres humanos. Não foi apenas transportado: mudou na viagem, assim como os africanos escravizados também mudaram, fazendo história. Hoje, essa é a nossa transportadora de zika. 
Mosquitos e humanos têm linhas de tempo emaranhadas; a história da escravidão também é a história da evolução dos mosquitos e vice-versa. Mas, é claro, as vidas dos mosquitos são muito mais curtas que as vidas humanas, e isso é importante em termos de como cada espécie lida com as mudanças. Os mosquitos desenvolveram populações novas e virulentas, enquanto os plantadores brancos ainda estavam mexendo nas rotas para transportar africanos como propriedade. A atenção às cotemporalidades nos leva a diferenças entre espécies.

Em contraste com os seres humanos - e com os insetos - as árvores têm uma vida muito longa. A eficácia de matar insetos invasores, como aqueles que viajam em paletes de madeira, tem a ver com a incapacidade das árvores de encontrar respostas rápidas a novas ameaças de insetos. Quanto ao césio radioativo, ele tem uma meia-vida de mais de 30 anos - e somente em condições de laboratório; sob condições ecológicas, a radiação, reciclada por materiais orgânicos e movendo-se no solo, permanece muito mais tempo. Os frutos de mirtilo têm vida curta, mas a radioatividade se acumula em animais, como os humanos. À medida que trabalhamos através das temporalidades, todas essas questões devem ser colocadas em jogo. Através de coordenações dentro das cotemporalidades, são feitas histórias mais-que-humanas.

\section{Diferença Radical Forma Bordas Afiadas e Fricção Historicamente Produtiva}

Um dos motivos pelos quais concebemos o Atlas Feral como um projeto digital é que ele permite aos usuários viajar pelo casos e pelas escalas - como eu tenho feito aqui - para perceber como as dinâmicas ferais se empilham, se sobrepõem, e se diferenciam por meio das estruturas de paisagem. Pensar cotemporalidades nos permite notar as discrepâncias radicais ao longo de tipos variados de seres - e não obstante, precisamos ir e vir entre eles para conhecer as manchas e laços do Antropoceno. O mesmo vale para os tipos de conhecimento humano do Antropoceno. Os contribuidores do Atlas Feral trazem formas radicalmente diferentes de produzir conhecimento e experiência em seus verbetes no nosso projeto. A arquitetura digital permite aos usuários ir e vir entre os verbetes, experimentando com linhas de comparação e contraste, sem homogeneizá-los em um enquadre único. Dessa forma, um arcabouço digital parece ideal para abordar o dilema da representação após o progresso. A ampla multiplicidade de atores históricos, tão diferentes uns dos outros, pode ser recuperada através da movimentação dos usuários permitida pela estrutura digital do Atlas Feral.

Mas por que escolhemos chamá-lo de atlas? Essa questão leva à nossa interpretação do que seja mapear. Considere um ulmeiro da perspectiva do besouro da casca do ulmeiro. Besouros da casca cavam galerias na madeira sob a casca, para se alimentar e botar seus ovos; essas galerias se parecem com as ruas de uma cidade. Uma representação das galerias de besouros é um mapa no Atlas Feral, porque oferece um pedaço da estrutura de paisagem de um importante patógeno: a doença do ulmeiro holandesa, que devastou tantos ulmeiros na América do Norte e Europa. Os besouros da casca carregam um fungo não apenas pela árvore, mas também de uma árvore para outra. Sem os besouros, o fungo 
não consegue passar para uma nova árvore. Em um certo nível, portanto, a estrutura de paisagem do patógeno é definida pelos movimentos do besouro. As galerias dos besouros constituem um mapa no Atlas Feral porque sua representação nos oferece informação espacial. Os mapas do Atlas Feral não se encaixam numa mesma escala. Mesmo a escala comum do GIS, argumentamos, é enganadora, pois esconde suas lacunas e erros sob a falsa arte da padronização.

O Atlas Feral traz duas versões da doença do ulmeiro holandesa. Uma é uma memória pessoal da mortalidade repentina de ulmeiros no Reino Unido nos anos 1970, que mudou completamente o lar da escritora, para quem essas árvores eram um aspecto da identidade (WRIGHT, 2020). A outra é um relatório de um biólogo sobre formas de deslocamento e hibridização que permitiram ao fungo uma virulência inédita (BRASIER, 2020). O Atlas justapôs esses dois escritos, que incluem a autoridade de conhecimentos baseados em evidências, não obstante as diferenças significativas entre suas ontologias e epistemologias. Assim como nos recusamos a padronizar os mapas no Atlas, nos recusamos a padronizar os verbetes. Apropriamo-nos da "anarquia ontológica" de Eduardo Viveiros de Castro (2019). Abraçamos a diferença radical como modo de narrar o Antropoceno.

Para demonstrar o que quero dizer com isso, discutirei mais um mapa. Russell Ngadiyali Ashley (2020), um artista aborígene australiano, pintou para nós a relação entre seu povo e o sapo da cana invasor, que cobriu o Norte da Austrália. Seu clã é o dos lagartos goana, que comem sapos. Os sapos da cana têm glândulas venenosas no pescoço. Os predadores morrem quando pegam os sapos, antes de morder. Os lagartos de goana estão desaparecendo da terra de origem de Ashley. Ele escreve:

Antes, os goanas estiveram aqui para sempre. Antigamente, as pessoas passavam o tempo caçando-os. Agora, chegou um estrangeiro. Os napaki [brancos] chamam-no sapo da cana. Não o conhecemos, nem sabemos de onde veio. Mas ele veio e matou nossos animais, especialmente os dois goanas que chamamos de djanda e bidjay'. Agora, só comemos canguru, emu, tartaruga e alguns crocodilos. Não tem mais djanda. Não tem mais bidjay.

Quando os Yolngu foram procurar goana e encontraram tantos deles mortos, choraram por eles. Eles ainda choram. Talvez tenha sobrado alguns, onde o sapo da cana não consegue ir, mas não temos certeza...

Os Yolngu estão preocupados. Temos rituais e estórias para os djanda e bidjay'. Mas o sapo da cana chegou furtivamente, e espetou fatalmente os goanas e outros animais com sua lança de veneno. Ainda temos a lei, ainda podemos dançar para os djanda e bidjay', mas eles se foram. Ainda temos a lei, não esquecemos. Não vamos esquecer os goanas.

A pintura traz sapos da cana com lanças diante de homens que tentam afastá-los do povo, que celebra os goanas. Um círculo de pessoas canta; alguns choram. Isso é um mapa, pois representa a relação entre o povo e a terra. Mapas desse tipo já foram utilizados em casos judiciais envolvendo direitos territoriais dos australianos. Se eles forçam os limites da noção de mapa, esta é justamente a ideia.

O mapa de Ashley ilumina um dos principais propósitos do Atlas Feral. Cada verbete apresenta evidências em primeira mão de como a ação feral não humana constitui o Antropoceno. Mas os verbetes não são iguais, nem as relações dos autores com seus materiais. Cada um se comunica com o outro através de relações de diferença; eles às 
vezes recusam a lógica do outro. Agregá-los sem a expectativa de que formem um único mapa comum é o nosso objetivo. E não obstante, não deixamos o problema em termos de mundos que nunca se encontram: "Oriente é Oriente, e Ocidente é Ocidente." Com efeito, Ashley já está engajando num trabalho de comparação, ao escrever para um público que vai além do seu grupo, e que mistura várias línguas diferentes. No Atlas Feral, adotamos e estendemos a posição de Ashley. Por meio da arquitetura digital, experimentamos constantemente com sobreposições, comparações, linhas de conexão, e pontos de recusa. Juntos, esses verbetes mostram processos de estruturação da paisagem: nem um processo único, nem mundos diferentes desconectados; trata-se da produção ativa de mundos com muitos atores. Isso é o Antropoceno: fragmentado e planetário. Se os contribuidores imaginam e produzem mundos de modos diferentes, assim seja. O Altas Feral posiciona os verbetes lado a lado, e faz emergir um aparato performativo e lúdico para comparação e reflexão. Não pedimos aos contribuidores que sincronizassem os aparatos por meio dos quais produziram conhecimento sobre o material. Esperamos que os usuários encontrem essas diferenças no coração do Atlas Feral, e as utilizem para refletir sobre como um fenômeno planetário pode ser um sistema de coordenações parciais.

\section{A Comparação Pode ser Divertida e Performativa}

Um último ponto: uma abordagem empírica do antropoceno exige uma comparação lúdica e performativa entre escalas e processos incompatíveis, que, juntos, constituem o antropoceno irregular. Os antropólogos passaram o último século se preocupando se existe alguma maneira responsável de fazer comparação, com seu legado colonial. Quando recebi minha formação, a comparação simplesmente não foi feita; boa antropologia era imersão em um único local. Então surgiram múltiplas localizações, mas principalmente como uma cadeia de efeitos relacionados. Perguntar sobre o planetário enquanto recusase a homogeneização metodológica requer outra coisa. Ilustrei uma prática comparativa que não corresponde a uma autoridade colonial coerente. Talvez seja uma comparação feral, isto é, uma comparação que começa nas práticas imperiais de conhecimento, mas se recusa a permanecer na linha.

O Atlas Feral tem como objetivo mostrar esse conceito em nosso índice. Nossas entidades ferais estão alinhadas com precisão modernista, prontas para os usuários encontrarem as conexões. Mas logo abaixo da superfície, as palavras nadam e fluem. Aparecem entidades ferais não discutidas no Atlas, juntamente com categorias analíticas potenciais, mas não utilizadas. A solidez e sinceridade da categorização são postas em dúvida, mesmo no formato que a torna mais utilizável.

Que tipo de comparação é essa? Estamos pensando em brincadeira e performance como características de nossa coleção e comparação. O Atlas Feral oferece um desempenho improvisado de comparação - não uma classificação atemporal e autoritária. Nossa coleção e comparação não se destinam à palavra final. Vemos o projeto como uma porta que abrimos, esperando que os usuários observem possíveis caminhos além. São possíveis novas formas de pesquisa nas quais cientistas naturais e cientistas sociais não ocupem lados diferentes de uma grande divisão? Maneiras alternativas de conhecer os 
trechos da Terra poderiam ser parte de um todo não consensual? O Atlas Feral abre essas possibilidades.

\section{Referências}

ASHLEY, Russell Ngadiyali. Before, goannas were here forever. In: TSING, Anna et al. (org.). Feral atlas: the more-than-human Anthropocene. Stanford: Stanford University Press, 2020. Disponível em: feralatlas.org. Acesso em: 2 maio 2019.

BRASIER, Clive. Introduced pathogens can evolve rapidly, increasing their virulence. In: TSING, Anna et al. (org.). Feral atlas: the more-than-human Anthropocene. Stanford: Stanford University Press, 2020. Disponível em: feralatlas.org. Acesso em: 2 maio 2019.

BROWN, Kate. Plutopia: atomic cities, and the great soviet and American plutonium disasters. Oxford: Oxford University Press, 2013.

BROWN, Kate. Chernobyl is going global. In: TSING, Anna et al. (org.). Feral atlas: the more-than-human Anthropocene. Stanford: Stanford University Press, 2020. Disponível em: feralatlas.org. Acesso em: 2 maio 2019.

CYPHER, Rachel. Love in the Anthropocene. 2020. Dissertation (Mestrado) - Department of Anthropology, University of California, Santa Cruz, 2020.

EBRON, Paulla A. Slave ships were incubators for infectious diseases. In: TSING, Anna et al (org.). Feral atlas: the more-than-human Anthropocene. Stanford: Stanford University Press, 2020. Disponível em: feralatlas.org. Acesso em: 2 maio 2019.

EBRON, Paulla A. forthcoming. Making Tropical Africa in the Georgia Sea Islands. Manuscript in preparation. [no prelo].

FABIAN, Johannes. Time and the Other: How Anthropology Makes its Object. New York: Columbia University Press, 1983.

FOSTER, John Bellamy. Marx's Theory of Metabolic Rift: Classical Foundations for Environmental Sociology. The American Journal of Sociology, [s.l.], v. 105, n. 2, p. 366405, 1999.

HADFIELD, Michael. Snails that eat snails. In: TSING, Anna et al. (org.). Feral atlas: the more-than-human Anthropocene. Stanford: Stanford University Press, 2020. Disponível em: feralatlas.org. Acesso em: 2 maio 2019.

McNEIL, John. Mosquito Empires: Ecology and War in the Greater Caribbean, 1620-1914. Cambridge: Cambridge University Press, 2010.

MILON, Anne-Sophie; ZALASIEWICZ, Jan. The victims of carbon dioxide are starting to appear. In: TSING, Anna et al. (org.). Feral atlas: the more-than-human Anthropocene. Stanford: Stanford University Press, 2020. Disponível em: feralatlas.org. Acesso em: 2 maio 2019.

NAGY, Kelsi. Plastics Saturate Us, Inside and Outside Our Bodies. In: TSING, Anna et al. (org.). Feral atlas: the more-than-human Anthropocene. Stanford: Stanford University Press, 2020. Disponível em: feralatlas.org. Acesso em: 2 maio 2019.

PERFECTO, Ivette. Coffee rust spreads together with coffee plantations. In: TSING, Anna et al. (org.). Feral atlas: the more-than-human Anthropocene. Stanford: Stanford University Press, 2020. Disponível em: feralatlas.org. Acesso em: 2 maio 2019.

POWELL, J. R.; TABACHNICK, W. J. History of domestication and spread of Aedes aegypti - a review. Mem. I. Oswaldo Cruz 108, suppl., [s.l.], v. 1, p. 11-17, 2013. 
TSING, Anna; MATHEWS, Andrew; BUBANDT, Nils. Patchy Anthropocene: Landscape Structure, Multispecies History, and the Retooling of Anthropology. Current Anthropology, [s.l.], v. 60, n. 20, p. 186-197, 2019.

VIVEIROS DE CASTRO, Eduardo. On Models and Examples: Engineers and Bricoleurs in the Anthropocene. Current Anthropology, [s.l.], v. 60, n. 20, p. 296-308, 2019.

WEISS, Marissa. Unexpected Threats to Trees Can Be Traced to Wood Pallets. In: TSING, Anna et al. (org.). Feral atlas: the more-than-human Anthropocene. Stanford: Stanford University Press, 2020. Disponível em: feralatlas.org. Acesso em: 2 maio 2019.

WRIGHT, Sue. I've lost the smell of elm dust. In: TSING, Anna et al. (org.). Feral atlas: the more-than-human Anthropocene. Stanford: Stanford University Press, 2020. Disponível em: feralatlas.org. Acesso em: 2 maio 2019.

\section{Anna Tsing}

Doutora em Antropologia pela Universidade de Stanford. Professora de Antropologia na Universidade da Califórnia Santa Cruz (UCSC).

Endereço profissional: UC Santa Cruz, 1156 High Street, Santa Cruz, Ca 95064. Anthropology

Department, Social Sciences 1, office 411.

E-mail: atsing@ucsc.edu

ORCID: https://orcid.org/0000-0002-0411-959X

\section{Como referenciar este artigo:}

TSING, Anna. O Antropoceno mais que Humano. Ilha - Revista de Antropologia, Florianópolis, v. 23, n. 1, p. 176-191, 2021. 